\title{
ANALISIS INDEKS KONDISI KEUANGAN PEMERINTAH DAERAH PROVINSI ACEH TAHUN 2015-2017
}

\author{
Irna Mardi Yati ${ }^{1}$, Jhon Andra Asmara*2 \\ 1,2Program Studi Akuntansi Fakultas Ekonomi dan Bisnis Universitas Syiah Kuala \\ e-mail: irnamardiyati04@gmail.com ${ }^{1}$,jhon.andra@unsyiah.ac.id ${ }^{* 2}$
}

\section{* Corresponding Author}

\begin{abstract}
Abstrak
The study aims to analyze the region's financial state in aceh within 2015-2017. The financial condition is measured by using indexing measures developed by ritonga (2014), which are made up of six dimensions of short term solvability, long-term solvability, budget solvability, financial flexibility, financial independence, service solvability. In 2015, analysis was developed by augmenting the operational solvability dimension. This study is using qualitative descriptive methods and analysed a secondary data obtained through documentary techniques. The result of this study shows that within 3 years the financial district/city in aceh that got the best category of index value is Sabang (0.488), Banda Aceh (0.452), Aceh Tengah (0.444), Aceh Besar (0.389), and Gayo Lues (0.382). While the area government with the value of the financial conditions of the lowest financial level or ranked category is Aceh Tenggara (0,177), Aceh Singkil $(0,148)$ Lhokseumawe $(0,106)$.
\end{abstract}

Keywords: Region government, financial state, short-term solvability, long-term solvability, budget solvability, financial flexibility, financial independence, solvability services, solvability, operation solvability

\section{Pendahuluan}

Otonomi daerah yaitu adanya hak, wewenang dan kewajiban daerah otonom untuk mengatur serta mengurus sendiri urusan pemerintahan dan kepentingan masyarakat setempat berdasarkan aspirasi masyarakat sesuai peraturan perundang-undangan (Seymour \& Turner, 2002). Adapun perimbangan keuangan antar pemerintah pusat dan daerah adalah pemerataan antara daerah secara proporsional, demokratis, adil, serta transparan dengan memperhatikan potensi, kondisi, dan kebutuhan daerah sejalan dengan kewajiban dan pembagian kewenangan tersebut, termasuk pengelolaan dan pengawasan keuangannya (Kharisma, 2013).

Salah satu aspek otonomi daerah adalah desentralisasi pengelolaan keuangan yaitu hak-hak yang diberikan kepada pemerintah daerah untuk mengelola pendapatan, belanja dan pendanaan (Firman, 2009). Dalam desentralisasi pengelolaan keuangan, pemerintah pusat juga memberikan prinsip-prinsip dalam pengelolaan keuangan daerah kepada pemerintah daerah tetapi bukan aturan secara rigid (Wickremasinghe \& Irwan, 2012). Oleh sebab itu kondisi keuangan antara pemerintah daerah yang satu dengan pemerintah daerah yang lain bervariasi.

Variasi dalam kondisi keuangan tersebut dapat menciptakan suatu kebutuhan bagi para pemangku kepentingan seperti parlemen pusat dan parlemen daerah, pemerintah pusat dan pemerintah daerah, dan masyarakat untuk melihat dan menilai tingkat kesehatan pemerintah daerah dalam mengelola keuangan (Prita, 2015). Selain itu, para pemangku kepentingan juga harus mengetahui faktor-faktor apa saja yang dapat menyebabkan variasi kondisi keuangan pemerintah daerah tersebut. Oleh karena itu di Indonesia, kebutuhan informasi tentang kesehatan kondisi keuangan pemerintah daerah menjadi sangat dibutuhkan sejak desentralisasi keuangan (Ritonga, 2014).

Pada era reformasi, sistem pemerintah daerah di Indonesia yang dikenal dengan otonomi daerah mengalami pengembangan menjadi otonomi khusus. Otonomi khusus diberikan oleh pemerintah pusat hanya kepada daerah- daerah tertentu, dikarenakan daerah tersebut memiliki keistimewaan yang tidak dimiliki oleh daerah-daerah lainnya di Indonesia (Malahayati, 2015). Terdapat lima provinsi yang diberikan otonomi khusus yaitu, Daerah Khusus 
Ibukota Jakarta, Daerah Istimewa Yogyakarta, Papua, Papua Barat, dan Aceh. Dari kelima provinsi tersebut terdapat tiga provinsi yang diberikan dana otonomi khusus yaitu Papua, Papua Barat dan Aceh.

Aceh memperoleh dana otonomi khusus di tahun 2008 hingga 2018 mencapai Rp 64,8999 triliun, rata-rata pertumbuhan dana otonomi khusus Aceh sebesar $8,59 \%$ menunjukkan rata-rata pertumbuhan yang sangat optimis jika dibandingkan dengan asumsi rata-rata pertumbuhan ekonomi Indonesia sebesar 5\% (Ikhsan, 2018). Semenjak Aceh memperoleh dana otonomi khusus, Aceh memprioritaskan penggunaan dananya untuk pendidikan, kesehatan, kesejahteraan sosial, infrastuktur serta keistimewaan aceh atau program-program konsumtif. Penggunaan dana ini dianggap kurang dimanfaatkan pada pembangunan sektor riil yang sebenarnya dapat meningkatkan Pendapatan Asli Daerah (Putri, 2018). Padahal, dana otonomi khusus di Aceh akan berakhir pada Tahun 2027 berdasarkan UU Pemerintahan Aceh. Hal tersebut mengakibatkan pentingnya bagi pemerintah untuk melihat kondisi keuangan Aceh guna mengetahui kesanggupan dan kesiapan yang perlu dilakukan pemerintah daerah dalam melakukan pembiayaan belanja daerah dan membayar utang secara mandiri setelah berakhirnya dana otonomi khusus.

Suatu pemerintah daerah dapat memberikan layanan publik yang baik kepada masyarakatnya apabila kondisi keuangannya baik. Sebaliknya, jika kondisi keuangan daerahnya buruk maka dapat dipastikan pemerintah daerah tersebut tidak mampu memberikan layanan publik yang baik dan memadai kepada masyarakatnya (Wang et al.,

2009). Para pengambil kebijakan di daerah harus memperhatikan dan menjaga kondisi keuangan pemerintah daerahnya dengan baik agar kualitas dan kuantitas layanan yang diberikan dapat dipertahankan atau ditingkatkan demi kesejahteraan masyarakatnya (Sijabat et al., 2012). Perhatian terhadap kondisi keuangan daerah ini bermaksud agar pemerintah daerah tidak mengalami kesulitan keuangan. Kesulitan keuangan yang terjadi ketika pemerintah daerah tidak dapat mempertahankan layanan dan memenuhi kebutuhan masyarakat (Ritonga, 2014) .

Penelitian ini bertujuan untuk Penelitian ini bertujuan untuk menganalisis kondisi keuangan
Pemkab/Pemkot di Provinsi Aceh selama periode tahun anggaran 2015-2017.

\section{Kerangka Pustaka \\ Kondisi Keuangan Pemerintah Daerah}

Secara umum, kondisi keuangan pemerintah daerah didefinisikan sebagai kemampuan suatu pemerintah dalam memenuhi kewajibannya baik dalam bentuk utang atau pemenuhan layanan secara berkelanjutan dan tepat waktu (Kioko, 2013 \& wang et al., 2007). Hal yang sama diungkapkan oleh Hurza (2015) bahwa penyediaan layanan dan kebutuhan yang dibutuhkan oleh masyarakat adalah suatu peran pemerintah yang tidak bisa digantikan di era modern.

Ritonga (2014) menyimpulkan bahwa kondisi keuangan pemerintah daerah yaitu kemampuan keuangan suatu pemerintah daerah untuk memenuhi kewajibannya (kewajiban jangka pendek, kewajiban jangka panjang, dan kewajiban untuk memberikan layanan kepada masyarakat), untuk mengantisipasi kejadian tak terduga, dan untuk mengeksekusi hak keuangannya secara efektif dan efisien.

\section{Otonomi Daerah}

Berdasarkan UU No. 23 Tahun 2014, bab 1 pasal 1 otonomi daerah adalah hak dan kewajiban daerah otonom untuk mengatur dan mengurus sendiri urusan pemerintahan dan kepentingan masyarakat setempat berdasarkan aspirasi masyarakat sesuai peraturan perundang-undangan. Otonomi daerah terjadi akibat diterapkannya desentralisasi. Desentralisasi adalah penyerahan wewenang pemerintahan oleh pemerintah kepada daerah otonom untuk mengatur dan mengurus urusan pemerintahan dalam sistem Negara Kesatuan Republik Indonesia (Kharisma, 2013).

Tujuan dibentuknya otonomi daerah adalah terciptanya kemandirian daerah dalam meningkatkan kesejahteraan dan pelayanan publik, pengembangan kehidupan berdemokrasi, keadilan, pemerataan dan pemeliharaan hubungan yang cocok antar pusat dan daerah. Tertuju pada pertumbuhan ekonomi yang mendorong pemerintah daerah untuk melakukan pembangunan ekonomi dan mengelola sumber daya yang ada, agar terbentuknya suatu pola kemitraan dengan masyarakat untuk menciptakan lapangan pekerjaan yang baru, sehingga 
mempengaruhi perkembangan kegiatan ekonomi dalam daerah tersebut (Suparto, 2014).

\section{Pengelolaan Keuangan Daerah}

Pengertian pengelolaan keuangan daerah di dalam Peraturan Menteri dalam Negeri No. 13 Tahun 2006 adalah keseluruhan kegiatan yang meliputi perencanaan, pelaksanaan, penatausahaan, pelaporan, pertanggungjawaban, dan pengawasan keuangan daerah.

Halim dan Kusufi (2013:25) mengemukakan bahwa Keuangan daerah secara sederhana dapat diartikan sebagai semua hak dan kewajiban yang dapat dinilai dengan uang, demikian pula segala sesuatu baik berupa uang maupun barang yang dapat dijadikan kekayaan daerah sepanjang belum dimiliki/dikuasai oleh negara atau daerah yang lebih tinggi serta pihakpihak lain sesuai dengan ketentuan/peraturan perundangan yang berlaku.

\section{Pelaporan Keuangan Daerah}

Pelaporan keuangan daerah dilakukan oleh entitas pelaporan yang merupakan unit pemerintahan, terdiri dari satu atau lebih entitas akuntansi yang menurut ketentuan peraturan perundang-undangan wajib menyampaikan laporan pertanggungjawaban, berupa laporan keuangan. Berdasarkan Peraturan Pemerintah No. 71 Tahun 2010 laporan keuangan adalah laporan yang terstruktur mengenai posisi keuangan dan transaksi-transaksi yang dilakukan oleh suatu entitas pelaporan. Laporan keuangan juga harus memiliki ciri-ciri kualitas yang bagus meliputi relavan, handal (reliable), lengkap dan komprehensif (complete), serta dapat diperbandingkan (comparable) (Suryani dan Faisal, 2016).

\section{Agency Theory}

Teori keagenan (Agency Theory) secara umum diartikan sebagai suatu hubungan antara dua pihak ataupun lebih yang berperan menjadi pemberi wewenang (principal) dan penerima wewenang (agent) yang terkait dalam suatu kontrak. Pada dasarnya, teori keagenan ini menjelaskan hubungan antara pemegang saham selaku principal dengan perusahaan sebagai agent (Eisenhardt, 1989). Jensen dan Meckling (1976) mendefinisikan teori agensi sebagai sebuah teori yang menjelaskan hubungan kontrak antara dua orang atau lebih yang bertindak sebagai principal memerintah pihak lain yaitu agen untuk melakukan suatu jasa ataupun wewenang yang dilimpahkan sesuai dengan harapan principal.

Dalam struktur organisasi pemerintahan hubungan keagenan menjadi suatu konsep yang penting, karena aktivitas organisasi pemerintahan yang selalu berhubungan dengan pendelegasian wewenang. Dimulai dari pemberlakuan otonomi daerah dan desentralisasi yang diberikan oleh pemerintah pusat kepada pemerintah daerah sejak tahun 1999, desentralisasi telah membawa tantangan besar bagi pemerintah daerah dalam mencapai pemerintahan yang demokratis dan mampu menyediakan pelayanan yang baik bagi masyarakat (Zimmerman, 1997).

Pada hakikatnya, tujuan adanya organisasi sektor publik untuk memberikan pelayanan kepada masyarakat atas barang atau sumber daya yang digunakan untuk memenuhi kebutuhan hidup banyak orang. Rakyat yang mengawasi prilaku pemerintah dan menyesuaikan tujuan yang diinginkan oleh rakyat dengan tujuan pemerintan. Dalam melakukan pengawasan tersebut rakyat mewajibkan pemerintah untuk mempertanggungjawabkan pengelolaan sumber daya yang diamanahkan kepada pemerintah melalui pelaporan keuangan secara periodik. Legislatif sebagai wakil rakyat mengukur, menilai serta mengawasi kinerja pemerintah, untuk melihat sejauh mana pemerintah telah bertindak dalam meningkatkan kesejahteraan rakyat (Halim dan Syukriy, 2006).

\section{Metode Penelitian}

\section{Desain Penelitian}

Tujuan dalam penelitian ini bersifat studi deskriptif, yaitu mendeskripsikan kondisi keuangan Pemkab/Pemkot di Provinsi Aceh berdasarkan Standar Akuntansi Pemerintah (PP No. 24/2005, PP No. 71/2010) dengan menggunakan enam dimensi keuangan yang dibangun oleh Ritonga (2014) dan ditambah satu dimensi solvabilitas operasional.

Strategi penelitian dalam penelitian ini menggunakan strategi penelitian dokumentasi. Dalam penelitian ini peneliti akan menganalisis Laporan Keuangan Pemerintah Daerah (LKPD) yang sudah di audit oleh Badan Pemeriksa Keuangan (BPK) untuk mengetahui bagaimana kondisi keuangan pemerintah daerah di Aceh. Situasi studi pada 
penelitian ini adalah situasi tidak diatur atau situasi alami. Tingkat intervensi dalam penelitian ini adalah intervensi minimal. Unit analisis dalam penelitian ini adalah adalah organisasi. Peneliti ingin meneliti unit analisis pada Pemkab/Pemkot di Provinsi Aceh.

\section{Populasi dan Sampel Penelitian}

Populasi dalam penelitian ini adalah seluruh Kabupaten/Kota di Aceh yang berjumlah 23 Kabupaten/Kota. Pengambilan sampel pada penelitian ini menggunakan metode sampel jenuh. Sehingga sampel dalam penelitian sama dengan populasi. Istilah lain dari sampel jenuh adalah sensus. Menurut Sugiyono (2003: 61-62) sampel jenuh adalah Teknik penentuan sampel bila semua objek populasi digunakan menjadi sampel.

\section{Jenis dan Sumber Data}

Jenis data yang digunakan dalam penelitian ini ialah data sekunder. Data sekunder adalah data yang diperoleh melalui sumber yang telah ada dan tidak perlu dikumpulkan sendiri oleh peneliti berupa tabel, grafik dan laporan (Sekaran \& Bougie, 2017: 130).

Sumber data dalam penelitian ini diperoleh melalui Badan Pemeriksa Keuangan Republik Indonesia Perwakilan Provinsi Aceh berupa dokumen Laporan Hasil Pemeriksaan (LHP) atas Laporan Keuangan Pemerintah Daerah (LKPD) Pemkab/Pemkot di Provinsi Aceh tahun 2015-2017 dan Laporan Data Sosial Ekonomi yang dikumpulkan dari Badan Pusat Statistik Provinsi Aceh tahun 20152017.

\section{Definisi Operasionalisasi Variabel}

Ritonga (2014) mendefinisikan kondisi keuangan pemerintah daerah menunjukkan kemampuan keuangan suatu pemerintah daerah untuk memenuhi kewajibannya (kewajiban jangka pendek, kewajiban jangka panjang, dan kewajiban untuk memberikan layanan kepada masyarakat) untuk mengantisipasi kejadian tak terduga, dan untuk mengeksekusi hak keuangannya secara efektif dan efisien. Dokumen yang digunakan dalam penelitian ini berupa Laporan Data Sosial Ekonomi dan Laporan Keuangan Pemerintah Daerah (LKPD) yang telah di audit oleh Badan Pemeriksa Keuangan (BPK).

Selanjutnya, terdapat enam dimensi dalam menganalisis indeks kondisi keuangan pemerintah daerah yaitu solvabilitas jangka pendek, solvabilitas jangka panjang, solvabilitas anggaran, fleksibilitas keuangan, kemandirian keuangan, solvabilitas layanan dan ditambah satu dimensi solvabilitas operasional.

Solvabilitas keuangan jangka pendek artinya pemerintah daerah mampu memenuhi kewajiban yang sudah jatuh tempo dalam jangka waktu 30 hari hingga 1 tahun. Solvabilitas keuangan jangka panjang artinya kemampuan pemerintah daerah dalam melunasi kewajiban jangka panjangnya dalam kurun waktu diatas 1 tahun. Solvabilitas anggaran artinya menggambarkan keterampilan pemerintah daerah dalam menghasilkan pendapatan untuk memenuhi operasinya selama periode anggaran berjalan. Fleksibilitas keuangan artinya suatu kondisi dimana pemerintah daerah mampu meningkatkan keuangannya dan mengatasi kejadian tak terduga dimasa yang akan datang. Kemandirian keuangan artinya suatu kondisi dimana pemerintah daerah mampu mengeksekusi hak-hak keuangannya secara efektif dan efisien. Solvabilitas Layanan artinya menunjukkan kapasitas keuangan pemerintah daerah untuk menyediakan dan mempertahankan kualitas pelayanan publik yang dibutuhkan dan diinginkan oleh masyarakat. solvabilitas operasional artinya kesanggupan keuangan suatu pemerintah daerah dalam membiayai operasinya salama periode anggaran. Secara ringkas dimensi dan indikator pengukuran Indeks Kondisi Keuangan dapat dilihat pada Tabel berikut

\section{Tabel 1}

Dimensi dan Indikator Indeks Kondisi Keuangan

\begin{tabular}{|c|l|c|}
\hline Dimensi & \multicolumn{1}{|c|}{ Indikator } & Jenis Pengukuran \\
\hline Solvabilitas & Rasio A = (Kas dan Setara Kas + Investasi Jk. Pendek)/Kewajiban Lancar & \\
\cline { 2 - 2 } Keuangan Jk. & Rasio B = (Kas dan Setara Kas + Investasi Jk. Pendek)/Kewajiban Lancar & \\
\cline { 2 - 2 } Pendek & Rasio C = Aktiva Lancar/Kewajiban Lancar & \\
\hline Solvabilitas & Rasio A = Total Aset/Kewajiban Jangka Panjang & \multirow{2}{*}{ Rasio } \\
\cline { 2 - 2 } $\begin{array}{c}\text { Keuangan Jk } \\
\text { Panjang }\end{array}$ & Rasio B = Total Aset/Total Kewajiban & \\
\cline { 2 - 3 } & Rasio C = Ekuitas Dana Investasi/Total & \\
\end{tabular}




\begin{tabular}{|c|c|c|}
\hline Dimensi & Indikator & Jenis Pengukuran \\
\hline \multirow{4}{*}{$\begin{array}{l}\text { Solvabilitas } \\
\text { Anggaran }\end{array}$} & Rasio A = (Total Pendapatan-Pendapatan DAK $) /($ Total Belanja - Belanja Modal $)$ & \multirow{4}{*}{ Rasio } \\
\hline & Rasio B = (Total Pendapatan-Pendapatan DAK $) /$ Belanja & \\
\hline & Rasio C = (Total Pendapatan-Pendapatan DAK)/ Belanja Pegawai & \\
\hline & Rasio D = Total Pendapatan/Total Belanja & \\
\hline \multirow{4}{*}{$\begin{array}{l}\text { Fleksibilitas } \\
\text { Keuangan }\end{array}$} & $\begin{aligned} \text { Rasio A }= & (\text { Total Pendapatan }- \text { DAK }- \text { Belanja Pegawai }) /(\text { Pembayaran Pokok } \\
& \text { Pinjaman }+ \text { Belanja Bunga })\end{aligned}$ & \multirow{4}{*}{ Rasio } \\
\hline & Rasio B = (Total Pendapatan - DAK - Belanja Pegawai)/Jumlah Kewajiban & \\
\hline & $\begin{aligned} \text { Rasio C }= & \text { (Total Pendapatan }- \text { DAK }- \text { Belanja Pegawai }) / \text { Kewajiban Jangka } \\
& \text { Panjang }\end{aligned}$ & \\
\hline & Rasio D = (Total Pendapatan - DAK $) /$ Jumlah Kewajiban & \\
\hline \multirow{2}{*}{$\begin{array}{c}\text { Kemandirian } \\
\text { Keuangan }\end{array}$} & Rasio A = Total PAD/Total Pendapatan & \multirow{2}{*}{ Rasio } \\
\hline & Rasio B = Total PAD/Total Belanja & \\
\hline \multirow{5}{*}{$\begin{array}{l}\text { Solvabilitas } \\
\text { Layanan }\end{array}$} & Rasio A = Total Ekuitas/Jumlah Penduduk & \multirow{5}{*}{ Rasio } \\
\hline & Rasio B = Total Aset/Jumlah Penduduk & \\
\hline & Rasio C = Total Aset Tetap/Jumlah Penduduk & \\
\hline & Rasio D = Total Belanja/Jumlah Penduduk & \\
\hline & Rasio E = Total Belanja Modal/Jumlah Penduduk & \\
\hline \multirow{4}{*}{$\begin{array}{l}\text { Solvabilitas } \\
\text { Operasional }\end{array}$} & Rasio A = (Total Pendapatan LO - Pendapatan DAK LO $) /$ Total Beban & \multirow{4}{*}{ Rasio } \\
\hline & Rasio B = (Total Pendapatan LO - Pendapatan DAK LO $) /$ Beban Operasional & \\
\hline & Rasio C $=($ Total Pendapatan LO - Pendapatan DAK LO $) /$ Beban Pegawai & \\
\hline & Rasio I & \\
\hline
\end{tabular}

Sumber: Ritonga (2015)

\section{Teknik Analisis Data}

Teknis analisis data yang digunakan dalam penelitian ini ialah kualitatif menggunakan tujuan studi deskriptif. Langkah-langkah analisis data dalam penelitian ini adalah sebagai berikut:

1) Menghitung rasio masing-masing dimensi.

2) pengukuran indeks komposit kondisi keuangan daerah yang dibangun oleh Ritonga (2014).

a) Menghitung indeks Rasio, dengan rumus:

$$
I R X i=\frac{(\text { Nilai } X \text { aktual }(n)-\text { Nilai } X \text { terendah }}{(\text { Nilai } X \text { tertinggi }- \text { Nilai } x \text { terendah }}
$$

b) Menghitung Ideks Dimensi

Indeks dimensi adalah rata-rata aritmatika dari indeks rasio-rasio pembentuknya.

c) Menghitung Indeks Komposti Kondisi Keuangan Pemerintah Daerah

Indeks Komposit Keuangan pemerintah daerah adalah rata-rata tertimbang dari indeks-indeks dimensi, dengan rumus:

$$
F C I=\frac{\sum D I}{N}
$$

Dimana:

FCI $=$ indeks kondisi keuangan

$\sum \mathrm{DI}=$ total indeks dimensi

$\mathrm{n} \quad=$ jumlah dimensi

d) Pengkategorian atas Indeks Komposit Kondisi Keuangan Pemerintah Daerah.Secara ringkas pengkategorian dapat dilihat pada Tabel 2.

Tabel 2

\section{Pengkategorian}

\begin{tabular}{|c|c|l|}
\hline No & Penilaian & \multicolumn{1}{|c|}{ Keterangan } \\
\hline 1. & Baik & $\begin{array}{l}\text { jika nilai IKK lebih besar dari nilai } \\
\text { mean }+(1 \times \text { standar deviasi) }\end{array}$ \\
\hline 2. & Cukup & $\begin{array}{l}\text { jika nilai IKK berada diantara nilai } \\
\text { mean }-(1 \mathrm{x} \text { standar deviasi) dan } \\
\text { mean }+(1 \mathrm{x} \text { standar deviasi). }\end{array}$ \\
\hline 3. & Kurang & $\begin{array}{l}\text { jika nilai IKK kurang dari nilai } \\
\text { mean }- \text { (1 x standar deviasi). }\end{array}$ \\
\hline
\end{tabular}

Sumber: Ritonga (2014)

3) Penarikan kesimpulan dari hasil penelitian yang diperoleh 


\section{Hasil Dan Pembahasan}

\section{Hasil Penelitian}

Kondisi Keuangan Pemerintah Daerah Provinsi

Aceh Tahun 2015-2017

\section{Tabel 1}

Kondisi Keuangan Kabupaten/Kota di Aceh Tahun 2015-2017

\begin{tabular}{|c|c|c|c|c|c|c|c|c|c|c|}
\hline \multirow[b]{2}{*}{ Nama Pemda } & \multicolumn{7}{|c|}{ Indek Dimensi } & \multirow[b]{2}{*}{ Nilai IKK } & \multirow[b]{2}{*}{ Rank } & \multirow[b]{2}{*}{ Kategori } \\
\hline & $\begin{array}{l}\text { Solvabilitas } \\
\text { JK. Pendek }\end{array}$ & $\begin{array}{l}\text { Solvabilitas } \\
\text { JK. Paniang }\end{array}$ & $\begin{array}{r}\begin{array}{r}\text { Solvabilitas } \\
\text { Anggaran }\end{array} \\
\end{array}$ & $\begin{array}{r}\text { Kemandirian } \\
\text { Keuangan } \\
\end{array}$ & $\begin{array}{r}\text { Fleksibilitas } \\
\text { Keuangan } \\
\end{array}$ & $\begin{array}{c}\text { Solvabilitas } \\
\text { Lavanan }\end{array}$ & $\begin{array}{c}\text { Solvabilitas } \\
\text { Operasional }\end{array}$ & & & \\
\hline Kota Sabang & 1,000 & 0,333 & 0,388 & 0,187 & 0,500 & 1,000 & 0,008 & 0,488 & 1 & Baik \\
\hline Kota Banda Aceh & 0,283 & 0,444 & 0,215 & 1,000 & 0,557 & 0,189 & 0,473 & 0,452 & 2 & Baik \\
\hline Kabupaten Aceh Tengah & 0,002 & 0,336 & 0,556 & 0,825 & 0,504 & 0,345 & 0,537 & 0,444 & 3 & Baik \\
\hline Kabupaten Aceh Besar & 1,000 & 0,333 & 0,140 & 0,353 & 0,500 & 0,092 & 0,303 & 0,389 & 4 & Baik \\
\hline Kabupaten Gayo Lues & 0,047 & 0,035 & 0,737 & 0,024 & 0,054 & 0,970 & 0,809 & 0,382 & 5 & Baik \\
\hline Kota Subulussalam & 0,060 & 0,047 & 1,000 & 0,000 & 0,108 & 0,344 & 1,000 & 0,366 & 6 & Cukup \\
\hline Kabupaten Aceh Jaya & 0,020 & 0,024 & 0,543 & 0,064 & 0,034 & 0,968 & 0,616 & 0,324 & 7 & Cukup \\
\hline Kabupaten Nagan Raya & 0,000 & 0,000 & 0,799 & 0,390 & 0,001 & 0,354 & 0,660 & 0,315 & 8 & Cukup \\
\hline Kabupaten Pidie & 0,009 & 0,004 & 0,523 & 1,000 & 0,006 & 0,055 & 0,486 & 0,298 & 9 & Cukup \\
\hline Kabupaten Bener Meriah & 0,001 & 0,003 & 0,660 & 0,347 & 0,006 & 0,309 & 0,554 & 0,268 & 10 & Cukup \\
\hline Kabupaten Aceh Barat & 0,005 & 0,005 & 0,381 & 0,743 & 0,006 & 0,474 & 0,232 & 0,264 & 11 & Cukup \\
\hline Kabupaten Aceh Barat Daya & 0,012 & 0,007 & 0,538 & 0,400 & 0,012 & 0,429 & 0,345 & 0,249 & 12 & Cukup \\
\hline Kabupaten Simelue & 0,017 & 0,005 & 0,473 & 0,253 & 0,017 & 0,540 & 0,408 & 0,245 & 13 & Cukup \\
\hline Kabupaten Pidie Jaya & 0,006 & 0,004 & 0,606 & 0,076 & 0,015 & 0,320 & 0,679 & 0,244 & 14 & Cukup \\
\hline Kabupaten Aceh Tamiang & 0,010 & 0,011 & 0,427 & 0,575 & 0,010 & 0,105 & 0,473 & 0,230 & 15 & Cukup \\
\hline Kabupaten Aceh Timur & 0,003 & 0,002 & 0,602 & 0,286 & 0,001 & 0,082 & 0,584 & 0,223 & 16 & Cukup \\
\hline Kabupaten Aceh Selatan & 0,002 & 0,002 & 0,359 & 0,534 & 0,002 & 0,285 & 0,363 & 0,221 & 17 & Cukup \\
\hline Kota Langsa & 0,110 & 0,055 & 0,217 & 0,478 & 0,090 & 0,090 & 0,502 & 0,220 & 18 & Cukup \\
\hline Kabupaten Aceh Utara & 0,000 & 0,000 & 0,676 & 0,692 & 0,001 & 0,060 & 0,066 & 0,214 & 19 & Cukup \\
\hline Kabupaten Bireun & 0,001 & 0,000 & 0,416 & 0,746 & 0,000 & 0,015 & 0,256 & 0,205 & 20 & Cukup \\
\hline Kabupaten Aceh Tenggara & 0,002 & 0,002 & 0,319 & 0,000 & 0,002 & 0,426 & 0,486 & 0,177 & 21 & kurang \\
\hline Kabupaten Aceh Singkil & 0,009 & 0,019 & 0,351 & 0,055 & 0,030 & 0,428 & 0,146 & 0,148 & 22 & kurang \\
\hline Kota Lhokseumawe & 0,000 & 0,000 & 0,071 & 0,076 & 0,000 & 0,017 & 0,580 & 0,106 & 23 & kurang \\
\hline
\end{tabular}

Sumber : Data diolah (2019)

Berdasarkan Tabel diatas Penilaian Indeks Komposit Kondisi Keuangan Kabupaten/Kota Tahun 2015-2017 terdapat 5 Kabupaten/kota di Aceh yang mendapatkan kategori indeks Baik antara lain, Kota Sabang $(0,488)$, Kota Banda Aceh $(0,452)$, Kabupaten Aceh Tengah (0,444), Kabupaten Aceh Besar $(0,389)$, dan Kabupaten Gayo Lues $(0,382)$.

Pada kategori indeks Cukup terdapat 15 Kabupaten/Kota. Selebihnya terdapat 3 Kabupaten/Kota yang menduduki kategori Indeks Kurang antara lain, Kabupaten Aceh Tenggara $(0,177)$ dan Kabupaten Aceh Singkil $(0,148)$ dan Kota Lhokseumawe $(0,106)$.

Tabel 4

Statistik Deskriptif Indeks Komposit Kondisi Keuangan Daerah Kabupaten/Kota di Aceh Tahun 2015-2017

\begin{tabular}{|l|c|c|c|c|c|c|}
\hline & N & Min & Max & Sum & Mean & $\begin{array}{c}\text { Std. } \\
\text { Deviation }\end{array}$ \\
\hline IKK & 69 & 0,106 & 0,488 & 6,471 & 0,281 & 0,099 \\
\hline $\begin{array}{l}\text { Valid N } \\
\text { (listwise) }\end{array}$ & 69 & & & & & \\
\hline
\end{tabular}

Sumber: Data diolah (2019)

Berdasarkan Tabel diatas dapat diketahui bahwa gabungan seluruh sampel kabupaten/kota selama tiga tahun penelitian berjumlah 69 LHP atas LKPD kabupaten/kota yang diteliti, nilai indeks terendah adalah 0,106 dan nilai indeks tertinggi adalah 0,488. Nilai jumlah keseluruhan indeks komposit kondisi keuangan ialah sebesar 6,471 dengan nilai mean sebesar 0,281. Mean pada tabel menunjukkan nilai rata-rata indeks komposit kondisi keuangan daerah di Aceh selama tahun anggaran 2015-2017. Nilai standar deviasi dalam statistik deskriptif ini adalah sebesar 0,099 . 


\section{Pembahasan}

\section{Kondisi Keuangan Pemerintah Daerah Provinsi Aceh Tahun 2015-2017}

Berdasarkan Tabel 4.2 dapat kita amati bahwa rata-rata indeks kondisi keuangan daerah masih berada pada kategori cukup dengan nilai mean hanya sebesar 0,281 dari 23 kabupaten/kota selama 3 tahun anggaran yang diteliti. Hal ini dapat dilihat pada sedikitnya kabupaten/kota yang memperoleh kategori baik. Hanya 5 kabupaten/kota yang memperoleh kategori baik dan selebihnya berada pada kategori cukup sejumlah 15 kabupaten/kota dan 3 kabupaten/kota bahkan memperoleh kategori kurang. Nilai tertinggi dengan kategori baik diperoleh Kota Sabang sebesar 0,488 dan nilai terendah dengan kategori kurang yaitu 0,106 diperoleh oleh Kota Lhokseumawe.

Perolehan kategori baik oleh 5 kabupaten/kota di Aceh dapat di artikan bahwa 7 dimensi pembentuk kondisi keuangan pemerintah daerah pada 5 kabupaten/kota tersebut sudah baik dimana kabupaten/kota mampu memenuhi kewajibannya baik dalam bentuk utang maupun pemenuhan layanan secara berkesinambungan. Kategori cukup yang paling banyak diperoleh kabupaten/kota memperlihatkan bahwa rata-rata kabupaten/kota di Aceh masih berada dalam kondisi keuangan yang cukup yang diartikan bahwa kabupaten/kota masih harus meningkatkan nilai dimensi- dimensi pembentuk kondisi keuangan sehingga kemampuan dalam memenuhi kewajiban dan memberikan layanan publik yang baik kepada masyarakat dapat lebih memuaskan.

Berdasarkan Tabel 4.1 dapat dilihat dari 23 kabupaten/kota yang diteliti terdapat 3 kabupaten/kota memperoleh nilai indeks rendah. Rendahnya nilai indeks kondisi keuangan yang didapatkan oleh pemerintah kabupaten/kota menyimpulkan bahwa masih adanya kabupaten/kota yang belum dapat menjamin kelangsungan pemerintah daerahnya untuk memenuhi kewajibannya dalam bentuk utang, baik utang jangka pendek maupun utang jangka panjang serta kemampuan untuk mempertahankan kondisi keuangannya dan mengatasi kejadian tak terduga di masa yang akan datang. Kesehatan kondisi keuangan suatu pemerintah daerah dapat dilihat dari kemampuan daerahnya untuk memenuhi kewajibannya dalam bentuk utang maupun pemenuhan kebutuhan publik secara berkelanjutan dan tepat waktu (Kioko, 2013 \& Wang et al., 2007).
Hasil penelitian kondisi keuangan daerah ini sesuai dengan Agency Theory. Jika kita lihat hasil penelitian ini secara keseluruhan rata-rata indeks kondisi keuangan daerah berada pada kategori cukup bahkan beberapa sudah memasuki kategori baik walaupun masih terdapat 3 kabupaten/kota di kategori kurang maka, esensi dari Agency Theory hampir terealisasi secara sempurna. Hal ini dapat dibuktikan dari kinerja pemerintah kabupaten/kota yang berusaha untuk tidak mengabaikan kontrak yang telah dibuatnya bersama principal yaitu rakyat. Dalam kontrak tersebut pemerintah daerah wajib mempertanggungjawabkan pengelolaan sumber daya yang diamanahkan oleh rakyat, kemudian rakyat melihat sejauh mana pemerintah telah bertindak dalam meningkatkan kesejahteraan masyarakatnya (Halim dan Syukriy, 2006).

\section{Kesimpulan, Keterbatasan dan Saran Kesimpulan}

Penelitian ini bertujuan untuk menganalisis kondisi keuangan pemerintah daerah di Provinsi Aceh selama kurun waktu 2015-2017 dengan menggunakan model enam dimensi yang dikembangkan oleh Ritonga (2014) dan ditambah satu dimensi solvabilitas operasional. Total 69 data LHP atas LKPD yang digunakan dalam analisis ini. Berikut kesimpulan terkait penelitian yang dapat diambil:

Pada pemerintah daerah kabupaten/kota provinsi Aceh yang dianalisis, menunjukkan bahwa kondisi keuangan pemerintah daerah tahun 2015-2017 yang memperoleh kategori Baik dengan nilai indeks tertinggi adalah, Kota Sabang $(0,488)$, Kota Banda Aceh $(0,452)$, Kabupaten Aceh Tengah $(0,444)$, Kabupaten Aceh Besar (0,389), dan Kabupaten Gayo Lues $(0,382)$. Sedangkan pemerintah daerah yang menduduki kategori kurang dengan nilai indeks terendah adalah Kabupaten Aceh Tenggara $(0,177)$, Kabupaten Aceh Singkil $(0,148)$ dan Kota Lhokseumawe $(0,106)$.

\section{Keterbatasan Penelitian}

Dengan menggunakan metode pengukuran indeks komposit kondisi keuangan maka hasil dari penelitian ini tidak bisa dibandingkan dengan hasil penelitian dari daerah lainnya. Dikarenakan metode indeks komposit kondisi keuangan tidak bisa di generlisasikan. 


\section{Saran Akademis}

Berdasarakan hasil penelitian yang diperoleh, maka dapat ditemukan beberapa saran sebagai berikut:

1. Bagi pemerintah daerah yang memperoleh tren turun dan fluktuatif sebaiknya meninjau kembali kinerja keuangan baik itu pemasukan maupun pengeluaran sehingga dapat menjadi pertimbangan untuk anggaran di tahun berikutnya. Kemudian yang mengalami tren naik untuk dapat mempertahankannya.

2. Bagi pemerintah Kabupaten/Kota yang memiliki kondisi keuangan yang kurang sehat disarankan untuk melakukan hal-hal sebagai berikut:

a. Meningkatkan pengelolaan aset lancar dalam rangka menguatkan kemampuan memenuhi kewajiban, baik kewajiban jangka pendek maupun kewajiban jangka panjang.

b. Mendorong transaksi dan inovasi produk barang dan jasa yang dibuat oleh masyarakat, dengan memberikan pelatihan dan pemasaran pada usaha mikro, kecil, dan menengah. Sehingga dapat meningkatkan pendapatan asli daerah yang pada akhirnya akan meningkatkan kemandirian daerah.

c. Perubahan mindset pengelolaan keuangan daerah agar tidak hanya berorientasi pada tercapainya opini Wajar Tanpa Pengecualian (WTP) namun dapat terciptanya kondisi keuangan yang sehat dan berkelanjutan.

3. Bagi peneliti selanjutnya diharapkan dapat melanjutkan penelitian ke ranah yang lebih luas, seperti membandingkan antara provinsi satu dengan provinsi lainnya dan menggunakan metode pemeringkatan yang lain seperti metode rasio minimun.

\section{Daftar Pustaka}

Alam, A. B. M., Alam, M., \& Hoque, A. (2017). Measuring Financial Condition Of Urban Local Government: A Study Of Municipaities In Bangladesh. Journal of Developing Areas, 51(2), 71-84.

Baidori. (2015). Pengklasteran Pemerintah Daerah di Jawa dan Bali Berdasarkan Variabel Sosio ekonomi

(Komparasi Laporan keuangan Daerah). Tesis. Yogyakarta: Universitas Gadjah Mada.
Berne, R. \& Scramm, R. (2016). The Financial Analysis of Governments. Journal Of Education Finance, 13(2), 216-218.

Brusca, I. (2015). Drivers for the Financial Condition of Local Government: A Comparative. Journal Of Local Self- Government, 13(2), 161-184.

Cabaleiro, R., Buch, E., \& Vaamonde, A. (2012). Developing a Method to Assessing the Municipal Financial Health.

The American Review of Public Administration, 43(6), 729-751.

Carr, J., \& Brower, R. (2000). Principled Opportunism: Evidence from the Organization Middle. Journal Public Administration Quarterly, 24(Spring), 109-138.

CICA. (1997). Indicators of Government Financial Condition. Turonto: Canadian Institute of Chartered Accountants. Crosby, A, dan Robbins, D. (2013). Mission Impossible: Monitoring Municipal Fiscal Sustainability and Stress in

Michigan. Journal of Public Budgeting, Accounting, and Financial Management, 23(3), 522-555.

Cuadrado-Ballesteros, B, Mordan, N, GarciaSanchez, IM. (2014). Is Local Financial Health Associated with Citizens Quality of Life?. Soc Indic Res, 119, 559-580.

Eisenhardt, K. M. (1989). Agency Theory: An Assessment and Review. Academy of Management, 14(1), 57-74. Firman, T. (2009). Decentralization reform and local-government proliferation in indonesia: Towards a fragmentation of regional development. Review of Urban and Regional Development Studies, 21(2-3), 143157.

Halim, A \& Kusufi, M. . (2013). Akuntansi Sektor Publik: Akuntansi Keuangan Daerah. Edisi 4. Jakarta: Selemba Empat.

Halim, A \& Syukriy Abdullah . (2006). Hubungan dan Masalah Keagenan di Pemerintahan: Sebuah Peluang Penelitian Anggaran dan Akuntansi. Jurnal Akuntansi Pemerintah, 2(1), 53-64.

Hurza, F. (2015). Public sector organization financial ratios ' recent development as a matter of 
financial innovation. Journal Invesment Management and Financial Innovation, 12(2), 88-93.

Ikhsan, Muhammad. (2018). 'Redesign' Pengelolaan Dana Otsus Aceh. Diakses 04 April 2019. (https://serambinews.com/redesignpengelolaan-dana-otsus-aceh.html).

Jensen, M., \& Meckling, W. (1976). Theory of the firm: managerial behavior, agency costs, and ownership structure. Journal The Economic Nature of the Firm, 283-303.

Kamnikar , J. A., Kamnikar , E. \& Deal, K. H. (2006). Assessing a State's Financial Condition. Journal of Government Financial Management, 55(30).

Kartiwa, H. A. (2004). Proses Penyusunan Anggaran Pendapatan dan Belanja Daerah (APBD) dan Arah Kebijakan Umum. Makalah Yang Disampaikan Pada Pelatihan Pendalaman Kompetensi Bidang Tugas Legislatif Anggota DPRD Kabupaten Sukabumi, Pada Tanggal 8 Desember.

Kharisma, B. (2013). Desentralisasi Fiskal Dan Pertumbuhan Ekonomi : Sebelum Dan Sesudah Era Desentralisasi Fiskal Di Indonesia. Jurnal Ekonomi Dan Studi Pembangunan, 14(2), 101119.

Kioko, S. (2013). Riporting on the Financial Condition of the States 2002-2010. Journal of Public Budgeting, Accounting, and Financial Management, 20.

Kloha, P, Carol, SW, dan Kleine, R. (2005). Developing and a Composite Model Testing Predict Local Fiscal Distress to Predict Local Fiscal Distress. Journal Public Administration Review, 65(3), 313-323.

Lupia, A., \& Mc Cubbins, M. D. (2000). Representation or abdication? How citizens use institutions to help delegation succeed. European Journal of Political Research, 37(3), 291-307.

Maizunati, N. A. (2017). Kota Magelang Dalam Klaster Kota Di Jawa-Bali. Jurnal Riset Akuntansi Keuangan, 2, 140-162.

Malahayati. (2015). Otonomi Khusus untuk Aceh dan Papua Barat; Antara Teori dan Praktik dalam Kerangka Negara Kesatuan Republik Indonesia. Peaper Otonomi Khusus Dalam Sistem
Pemerintahan Indonesi, 1-42. Mardiasmo. (2002). Otonomi dan Manajemen Keuangan Daerah. Yogyakarta: Penerbit Andi.

Natrini, N. D., \& Ritonga, I. T. (2017). Design and Analysis of Financial Condition Local Government Java and Bali (2013-2014). Journal Economy and Business, 3003(32), 1-9.

Nollenberger, K., Groves, S. M. \& Valente, M. G. (2003). Evaluating Financial Condition: A handbook for local goverment. Washington, DC, International City/County Managers Association.

Prita, A. D. (2015). Analisis Kondisi Keuangan Berdasarkan Model Brown. Skripsi. Yogyakarta: Universitas Gadjah Mada.

Priyambodo, V.K. dan Ritonga, I. (2014). Mataram., Pengklasteran Pemerintah Daerah untuk Memaksimalkan Analisis Kondisi Keuangan Pemerintah Daerah. Simposium Nasional Akuntansi XVII.

Putri, R. D,. (2018). Dana Otsus Dicabut, Aceh Siap Bangkrut. Diakses 04 Februari 2019. (https://tirto.id/dana-otsus- dicabut-aceh-siapbangkrut-cP54.html).

Republik Indonesia. (1945). Undang-Undang Dasar Nomor 33 Tahun 1945 tentang Pengertian Perekonomian, Pemanfaatan SDA, dan Prinsip Perekonomian Nasional. . 2004. Undang-Undang Nomor 33 Tahun 2004 tentang Perimbangan Keuangan Antara Pemerintah Pusat dan Pemerintah Daerah.

. 2014. Undang-Undang Nomor 23 Tahun 2014 tentang Pemerintah Daerah.

2005. Peraturan Pemerintah Nomor 24 Tahun 2005 tentang Standar Akuntansi Pemerintahan.

. 2006. Peraturan Pemerintah Nomor 13 Tahun 2006 tentang Standar Akuntansi Pemerintahan.

. 2010. Peraturan Pemerintah No 71 Tahun 2010 tentang Standar Akuntansi Pemerintahan.

Ritonga, I. T. (2014). Developing A Measure Of Local Government's Financial Condition. Journal of Indonesia Economy and Business, 29(2), 142-164.

Ritonga, I. T. (2015). Analisis Laporan Keuangan Pemerintah Daerah. Artikel Magister Akuntansi Fakultas Ekonomi dan Bisnis 
Universitas Gadjah Mada.

Rivenbark, W. C., Roenigk, D. J., \& Allison, G. S. (2011). Communicating Financial Condition to Elected Officials in Local Government.Journal Public Administration Quarterly, 35, 241-267.

Rivenbark, W. C., Roenigk, D. J., \& Allison, G. S. (2010). Conceptualizing Financial Condition In Local Government. Journal of Public Budgeting, Accounting \& Financial Management, 22(2), 149-177.

Sekaran, U., \& Bougie, R. (2017). Metode Penelitian untuk Bisnis (6th ed.). Jakarta: Salemba Empat.

Seymour, R., \& Turner, S. (2002). Otonomi Daerah: Indonesia's Decentralisation Experiment. New Zealand Journal of Asian Studies, 4(2), 33-51.

Sijabat, M. Y., Saleh, C., \& Wachid, A. (2012). Analisis Kinerja Keuangan Serta Kemampuan Keuangan Pemerintah Daerah Dalam Pelaksanaan Otonomi Daerah (Studi Pada Dinas Pendapatan Daerah Dan Badan Pengelola Keuangan Dan Aset Daerah Kota Malang Tahun Anggaran 2008-2012). Jurnal Administrasi Publik (JAP), 2(2), 236-242.

Sugiyono. (2003). Metode Penelitian Bisnis. Bandun: Pusat Bahasa Depdiknas.

Sugiyono. (2013). Metode Penelitian Kuantitatif, Kualitatif, dan $R \& D$. Bandung: Alfabeta.

Suparto. (2014). OTONOMI DAERAH DI INDONESIA : Pengertian, Konsep , Tujuan , Prinsip dan Urgensinya. Jurnal Ilmu Hukum, 124.

Suryani dan, \& Faisal, H. B. (2016). Analisis Kondisi Keuangan Daerah Kabupaten/Kota Di Aceh Dan Di Sumatera Utara. Jurnal Bisnis Dan Ekonomi, 23(1), 63-71.

Trussel, JM, dan Patrick, PA (2009), A Predictive Model of Fiscal Distress in Local Government. Journal of Public Budgeting, Accounting, and Financial Management, 21(2), 578-616

Wang, X. dan L. (2009). Assesing the Change in Financial Condition: An Analaysis of Panel Data From U.S.States. Public Budgeting and Finance, 21(2), 165-197.

Wang, X., Dennis, L., Sen, Y., \& Tu, J. (2007). Measuring Financial Condition: A Study of $U$ . S . States. Public Budgeting \& Finance, 1-21.

Wickremasinghe, I. T. R. C. C. G., \& Irwan. (2012). Assessing financial condition of local government in Indonesia: an exploration" AUTHORS. Journal Public and Municipal Finance, 1(2), 37-50.

Zimmerman, B. J., \& Kitsantas, A. (1997). Developmental Phases in Self Regulation: Shifting From Process Goals to

Outcome Goals. Journal of Educational Psychology, (89), 29-3. 